doi: 10.52370/TISC21552TC

\title{
THE IMPORTANCE OF COMMUNICATION WITH DOMESTIC TOURISTS IN RECOVERING FROM COVID-19 PANDEMIC
}

\author{
Tatjana Cvetkovski ${ }^{l}$; Violeta Cvetkovska Tomanovic ${ }^{2}$
}

\begin{abstract}
At the time of the Covid-19 pandemic, when tourist traffic is falling sharply, domestic tourists become very important. They become the dominant or even the only source of income for tourism sector. This paper shows that due to the closure of countries in order to reduce the possibility of spreading disease, both the number of tourists and the number of overnight stays declined. However, in the summer months and during the holidays, domestic tourists filled capacities and resourceful individuals managed to take advantage of the opportunity that arose by adjusting their offer and/or tourist product. The conducted research is based on statistical data from the World Tourism Organization (UNWTO) and Statistical Office of the Republic of Serbia. Given the recovery period of the tourism sector as well as the possibility of new and similar diseases in the future, communication with domestic tourists will become increasingly important, as shown by this research.
\end{abstract}

Key Words: Domestic tourists, tourism sector, communication, Covid-19, pandemic, Serbia

JEL classification: $L 82, L 83, M 31, Z 32$

\section{Introduction}

"Tourism is one of the largest and fastest-growing economic sectors in the World. What reflects the new nature of tourism are: the development of mass tourism, the transition from organized tourist group travel to independent - solo travellers, the development of distant destinations,

\footnotetext{
${ }^{1}$ Tatjana Cvetkovski, PhD, Full Professor, Faculty of Business Studies, Bulevar marsala Tolbuhina 8, Novi Beograd, +381112203011, tcvetkovski@ megatrend.edu.rs

${ }^{2}$ Violeta Cvetkovska Tomanović, PhD, Associate Professor, Faculty of Culture and Media, Bulevar marsala Tolbuhina 8, Beograd, +381112203011, vcvetkovskaocokoljic@megatrend.edu.rs
} 
developing of package arrangements and shorter destinations" (Cvetkovski et al, 2016, p. 38). This was true until the beginning of 2020. Today the coronavirus pandemics is the most important characteristic of the world we live in, which affects the tourism sector as well.

"The coronavirus (COVID-19) pandemic is, first and foremost, a humanitarian crisis affecting people's lives, and has triggered a global economic crisis. This has very tangible impacts for the tourism sector, which is critical for many people, places and businesses, with the impact particularly felt in countries, cities and regions where tourism is an important part of the economy" (OECD, 2020a). "The tourism sector is currently one of the hardest-hit by the outbreak of COVID-19, with impacts on both travel supply and demand. This represents an added downside risk in the context of a weaker world economy, geopolitical, social and trade tensions, as well as uneven performance among major outbound travel markets" (UNWTO, 2020a).

Wider economy is affected by the coronavirus pandemic directly or indirectly. Tourism is a important part of many national economies, so the situation in the tourism sector, which is strongly influenced by the corona virus, is also reflecting on the broader economic situation of the country. "Tourism generates foreign exchange, drives regional development, directly supports numerous types of jobs and businesses and underpins many local communities. The sector directly contributes, on average, $4.4 \%$ of GDP, and $21.5 \%$ of service exports in OECD countries. For example, tourism in Spain contributes $11.8 \%$ of GDP while travel represents $52.3 \%$ of total service exports, in Mexico these figures are $8.7 \%$ and $78.3 \%$, in Iceland $8.6 \%$ and $47.7 \%$, in Portugal $8.0 \%$ and $51.1 \%$, and in France $7.4 \%$ and 22.2\%" (OECD, 2020b).

Although it is not yet possible to measure the full effects of the COVID-19 on tourism, some estimates exist. According to the UNWTO World Tourism Barometer "the collapse in international travel represents an estimated loss of USD 1.3 trillion in export revenues - more than 11 times the loss recorded during the 2009 global economic crisis. The crisis has put between 100 and 120 million direct tourism jobs at risk, many of them in small and medium-sized enterprises" (UNWTO, 2020d).

However, in many countries, the tourism sector started to promote domestic travel and has begun to appeal to visitors from its own country, because according to some experts, countries where domestic tourism has 
developed and significantly participated in the tourism economy are likely to recover faster than countries which largely depend on international tourists arrivals.

\section{Borders closure influence on tourism sector, international and domestic tourists in World and Europe}

Borders closure is highly connected with the current state of tourism sector, so the World Tourism Organization (UNWTO), in order to provide timely and accurate information in one place, launched the Tourism Recovery Tracker. The Tracker included data, among others, on COVID-19 related restrictions, due to many countries in Europe closed their borders in order to prevent transmission of COVID-19, especially at the very beginning of the pandemic.

Figure 1: COVID-19 Related Restrictions (1)

COVID - 19 RELATED TRAVEL RESTRICTIONS

- Complete Closurc $\bullet$ Other Measures • Partial Cosure
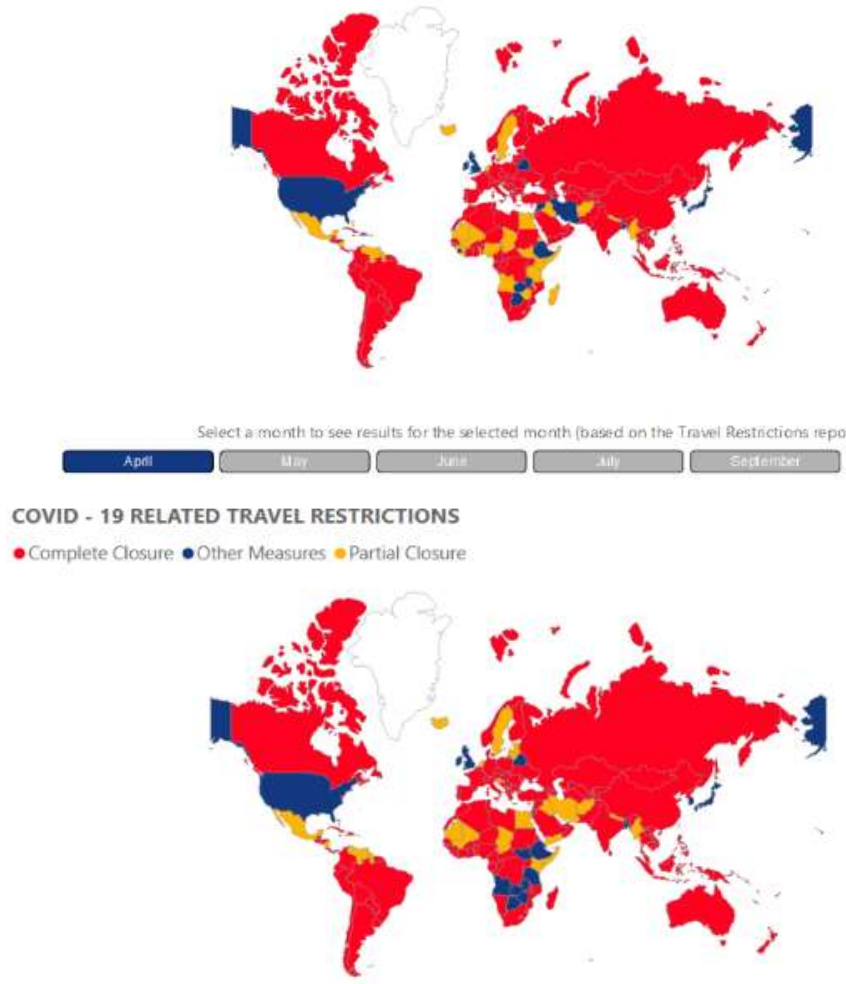

Select a month to see results for the selected month (based on the Travel Restrictions mport

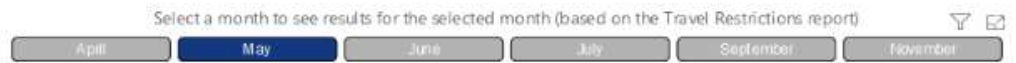

Source: UNWTO, $2021 \mathrm{~b}$ 
Figure 2: COVID-19 Related Restrictions (2)

COVID - 19 RELATED TRAVEL RESTRICTIONS

- Complete Closure e Litted For Tauram • Other Measures e Partial Closure
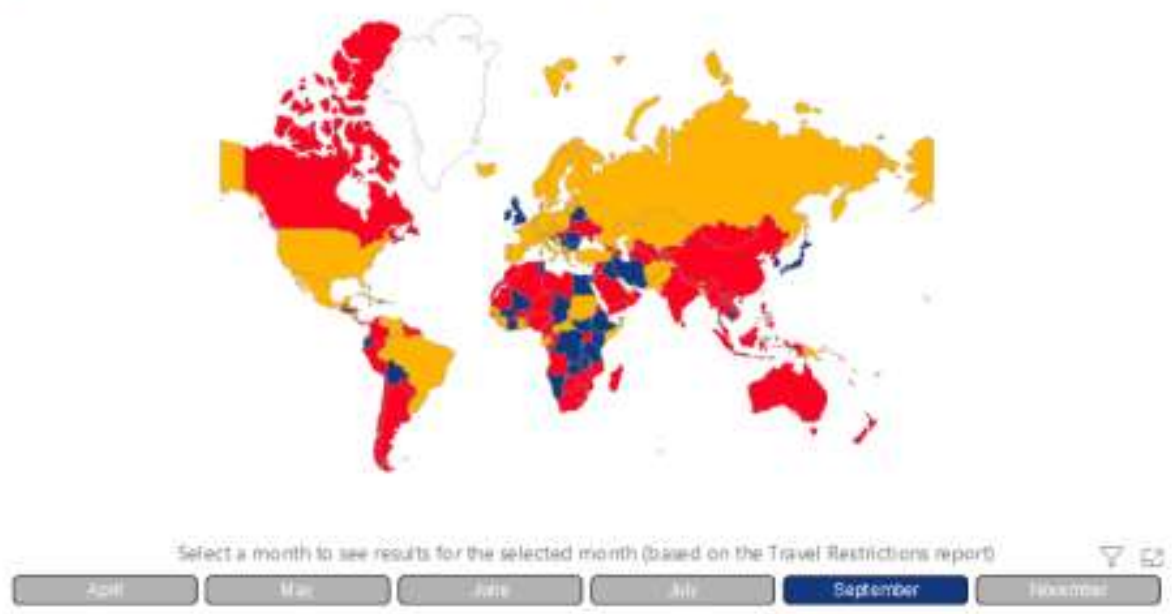

COVID - 19 RELATED TRAVEL. RESTRICTIONS

- Complete Closure • Lifted For Tourism • Other Measures e Partial Closure

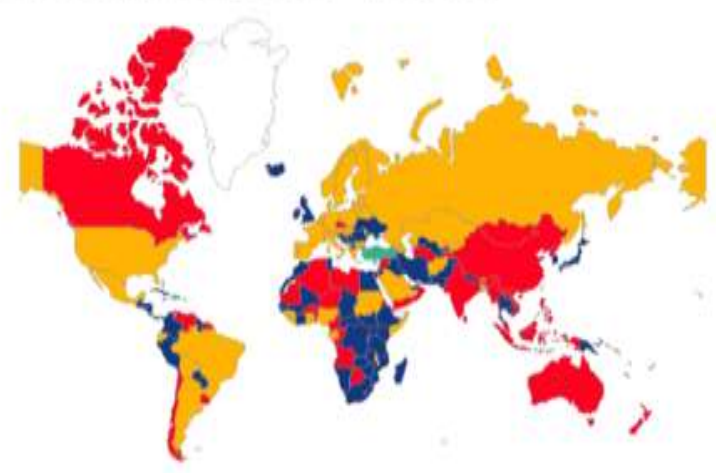

Select a month to see cosul ts for the selected month (based on the Travel Restrictions roport)

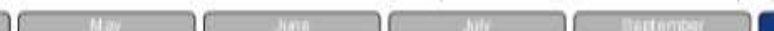

Source: UNWTO, $2021 \mathrm{~b}$

Figure 1 and 2 show border closure during April, May, September and November in the World. At the beginning of the pandemics, lots of countries completely closed their borders, but until November and December they relaxed measures.

COVID-19 related restrictions made a strong decrease in international arrivals in 2020. "Asia and the Pacific saw an $84 \%$ decrease in international arrivals in 2020, about 300 million less than in the previous year. The 
Middle East and Africa both recorded a 75\% drop in arrivals. In Europe arrivals declined by $70 \%$, representing over 500 million fewer international tourists, while the Americas saw a drop of 69\%" (UNWTO, 2021).

Figure 3: Decrease in international arrivals in 2020, by region

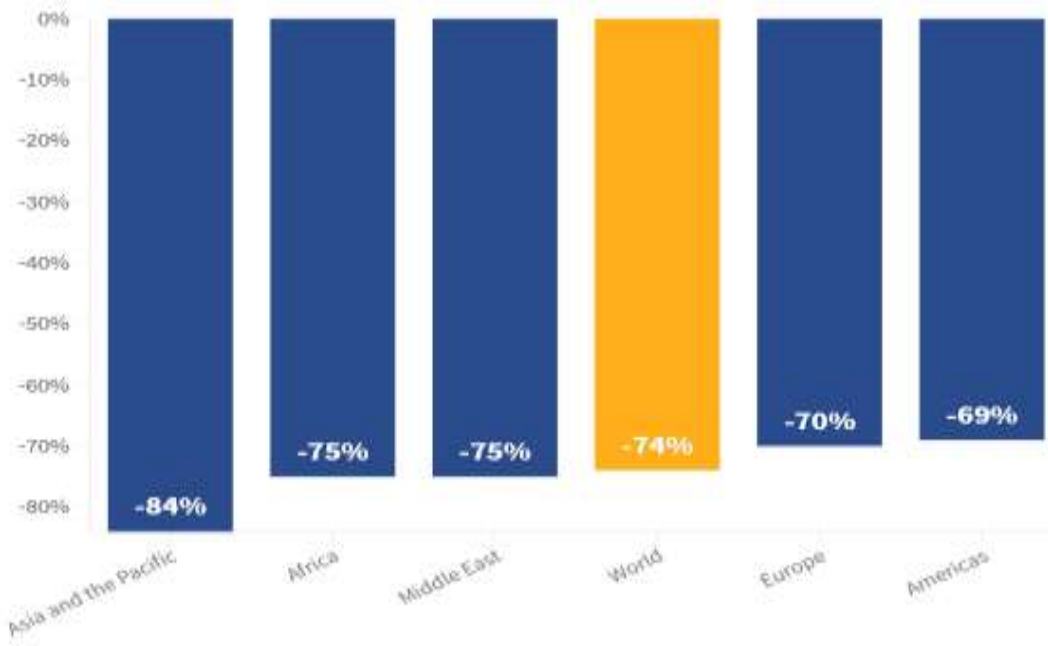

Source: UNWTO, $2021 a$

The latest Travel Restrictions Report shows that "70\% of all global destinations have eased restrictions on travel introduced in response to the COVID-19 pandemic" i.e. "as of 1 November, a total of 152 destinations have eased restrictions on international tourism, up from the 115 recorded on 1 September. At the same time, 59 destinations have kept their borders closed to tourists, a decrease of 34 over the same two-month period" (UNWTO, 2020b). It is interesting, they found in the same Travel Restrictions Report as well that "destinations with higher scores in health and hygiene indicators have eased restrictions faster than those with relatively low scores in health and hygiene indicators and environmental performance index" (usually from emerging economies). Those restrictions have had a huge impact on the tourism sector. In UNWTO (2020c) said "Small and medium sized enterprises (which make up around $80 \%$ of the tourism sector) are expected to be particularly impacted. This might affect millions of livelihoods across the world, including vulnerable communities who rely on tourism as a vehicle to spur their development and economic inclusion".

"International tourist arrivals in Europe, the world's most visited destination, were down $66 \%$ in the first half of 2020 over the same period 
last year, with a 97\% drop in the second quarter" (World Tourism Barometer, 2020). Travel restrictions and lockdowns greatly influenced the results of the first half of the year, because they were present as a trend in almost all destinations from the end of March and during the April and May. But, the UNWTO Panel of Experts foresees growing demand for open-air and nature-based tourism activities, with domestic tourism gaining increasing interest. "After a drop of $93 \%$ in April 2020 compared with the same month of the previous year, by July 2020, domestic tourism in the EU almost returned to the level of the previous year. In July 2020, nights spent by EU residents in tourist accommodation inside their own country were only $22 \%$ lower than in July 2019, while nights spent by non-residents were $64 \%$ less than the previous year" (Eurostat, 2020).

Figure 4: Relative importance of domestic tourism in OECD countries

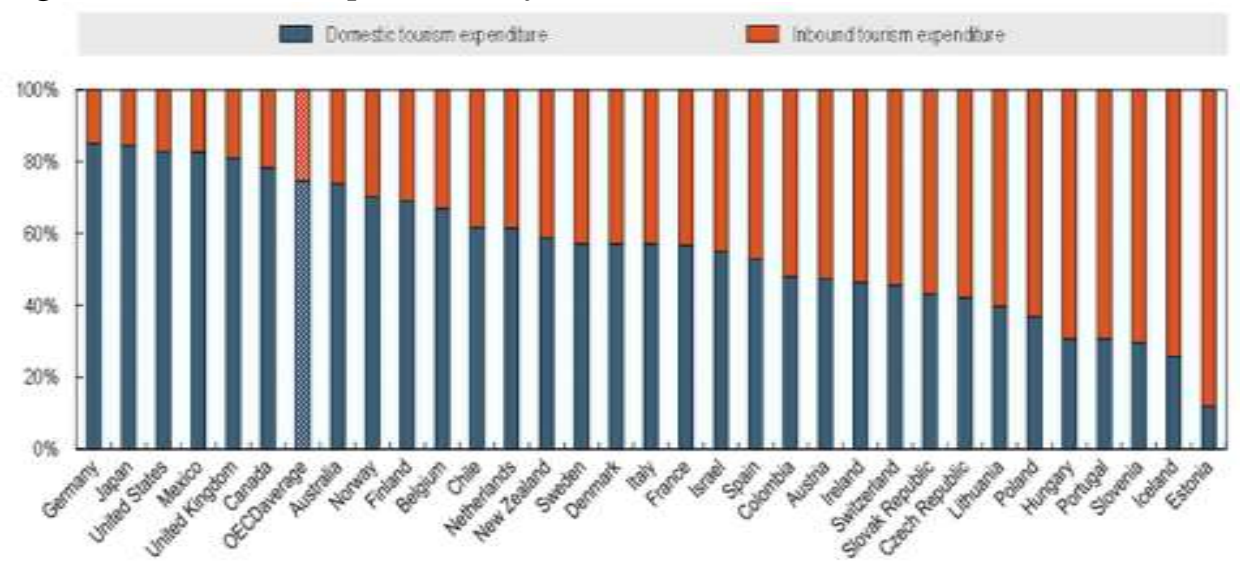

Source: OECD, $2020 \mathrm{~b}$

Although this figure varies among OECD countries, "before the crisis, domestic tourism accounted for $75 \%$ of tourism expenditures on average in OECD countries" OECD (2020b).

We need to think about measures that will led to recovery, bearing in mind that the survey of the UNVTO expert panel showed that experts see a return to the pre-pandemic level only after 2023. "In fact, $43 \%$ of respondents point to 2023, while $41 \%$ expect a return to 2019 levels in 2024 or later. UNWTO's extended scenarios for 2021-2024 indicate that it could take two-and-a-half to four years for international tourism to return to 2019 levels" (World Tourism Barometer, 2020) 
Figure 5: Expected return to pre-pandemic levels (World)

When do you expect international tourism to return to pre-pandemic 2019 levels in your country?

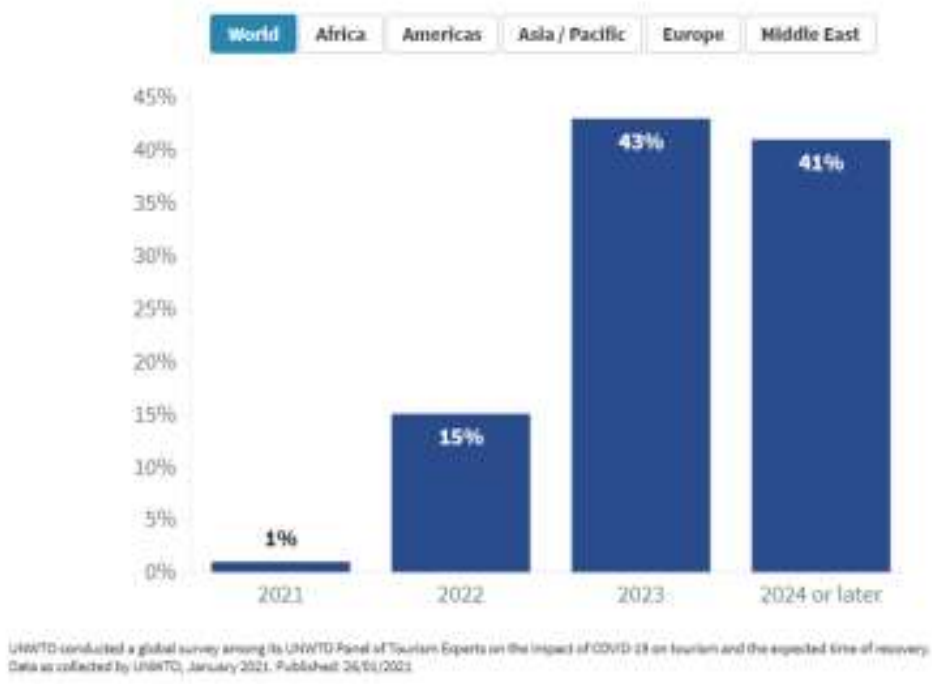

Source: UNWTO, $2021 a$

Figure 6: Expected return to pre-pandemic levels (Europe)

When do you expect international tourism to return to pre-pandemic 2019 levels in your country?

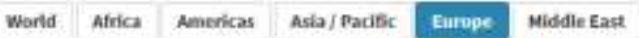

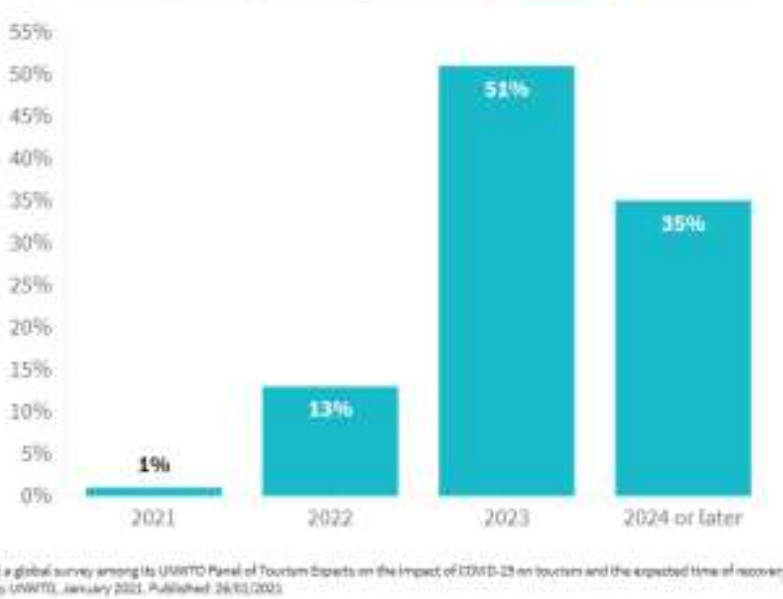

Source: UNWTO, $2021 a$

According to European Travel Commission (2020) "recovery will be led by domestic and short-haul travel. 
- The recovery of the Travel \& Tourism sector in coming years will vary across European destinations. This variation will in part be affected by the mix of travellers by different source market.

- Resilience of travel demand is greater for destinations that rely more heavily on domestic travellers and those from short-haul markets, which tend to be less volatile.

- The disruption to the Travel \& Tourism sector will also lead to changing travel patterns and provide the opportunity for destinations to target new sources of travel demand, including a potential in-crease in domestic and short-haul including some substitution from other longhaul destinations".

But, as they stated, some destinations are in better position than others (Serbia, as well according to Figure 7). "The combined Travel Potential Index points to destinations which may be in the best position to see a swifter and more stable recovery in Travel \& Tourism. However, other factors may impact on a destination's ultimate growth path in travel recovery. For example, the demographic profile of visitors is important. The destinations which have traditionally been more reliant on older travellers may face greater disruption if those travellers are more risk averse (due to health concerns)" European Travel Commission (2020).

Figure 7: Travel Potential Index for countries

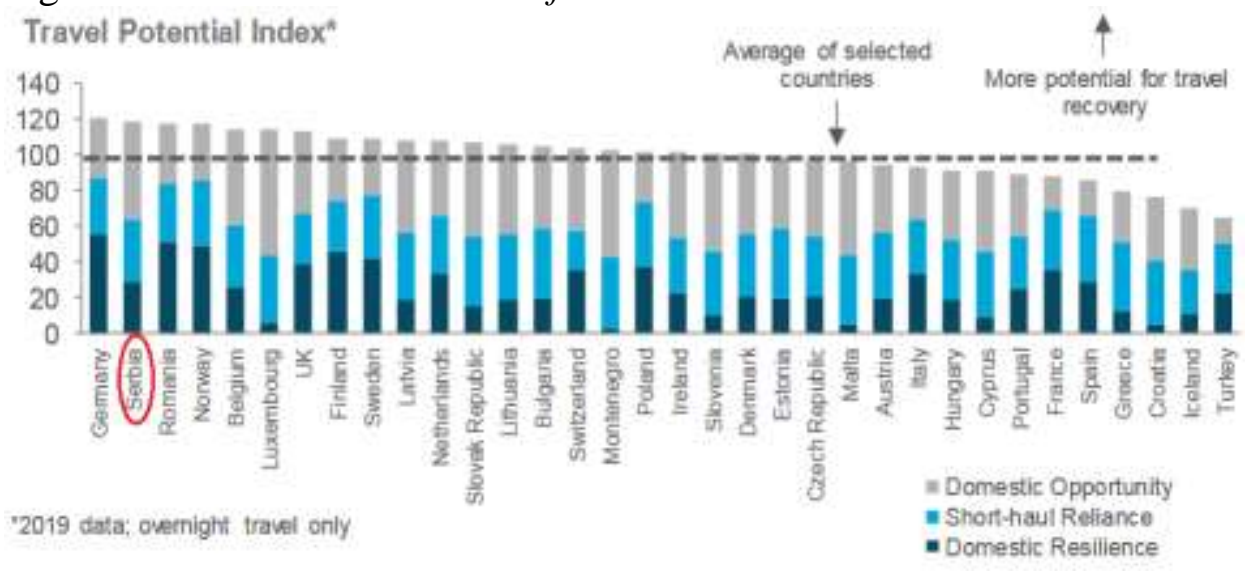

Source: European Travel Commission, 2020

Domestic tourism will play an important role in the early stages of recovery from a pandemic, given the fact that no one knows with certainty what will happen in the coming period with restrictions and international travels. 


\section{Borders closure influence on international and domestic tourists in Serbia}

From 2014 "an expansive growth of the tourism activity in Serbia started, which lasted till March 2020. At that time, due to the COVID-19 pandemic flights were forbidden, accommodation booking were canceled and the activity in the tourist sector recorded general fall" (Statistical Office of the Republic of Serbia, 2020a). "In 2019, the total number of tourists amounted to 3690 thousand, while the number of domestic tourists was 1843 thousand (7.6\% increase compared to 2018), and the number of foreign tourists who visited our country amounted to 1847 thousand, presenting the increase of $8.0 \%$ compared to 2018 . The realized number of all tourists' nights who were using the accommodation facilities was 10073 thousand, which was a $7.9 \%$ increase. There were 6063 thousand nights spent by domestic tourists (increase of $6.8 \%$ compared to 2018), while the number of overnight stays of foreign tourists was by $9.6 \%$ higher than in 2018 and it amounted to 4010 thousand of nights" (Statistical Office of the Republic of Serbia, 2020c).

Figure 8: Tourists' arrivals and overnight stays 2015-2019

\begin{tabular}{|ccc|}
\hline \multicolumn{3}{|c|}{ Republic of Serbia } \\
\multicolumn{4}{|c|}{ Total } \\
& Arrivals & Nights \\
2015 & 2437165 & 6651852 \\
2016 & 2753591 & 7533739 \\
2017 & 3085866 & 8325144 \\
2018 & 3430522 & 9336103 \\
2019 & 3689983 & 10073299 \\
\multicolumn{4}{|c}{ Dornestic } \\
2015 & 1304944 & 4242172 \\
2016 & 1472165 & 4794741 \\
2017 & 1588693 & 5150017 \\
2018 & 1720008 & 5679235 \\
2019 & 1843432 & 6062921 \\
\multicolumn{3}{|c}{ Forcign } \\
2015 & 1132221 & 2409680 \\
2016 & 1281426 & 2738998 \\
2017 & 1497173 & 3175127 \\
2018 & 1710514 & 3657868 \\
2019 & 1846551 & 4010378 \\
\hline
\end{tabular}

Source: Statistical Office of the Republic of Serbia, 2020c

The first case of COVID-19 in Serbia, reported on 6 March 2020. As of 22 February 2021, a total of "439,596 confirmed cases, 4,351 deaths, and 3,641 hospitalized cases have been reported in the country" (Ministry of Health of the Republic of Serbia, 2021). In the tourism sector, the situation 
has started to deteriorate from March, with the first case of COVID-19 and more sharply from April.

The most significant decrease $(94.6 \%)$ was recorded in April, while in the later months, although significantly less than in the same period last year, that number was higher. Over January-September 2020, domestic tourists represented the majority of visitors in Serbia, i.e. "80.8\% of the total number of overnight stays. In the third quarter of 2020 the number of domestic tourist overnight stays was by $13 \%$ larger than in the same quarter of the previous year. In the second quarter of 2020, the number of foreign tourist overnight stays to the same period of 2019 was down by $91.1 \%$. In the third quarter the number of foreign overnights stays was slightly larger but still by $82.1 \%$ less than in the same period of 2019" (Statistical Office of the Republic of Serbia, 2020a).

Figure 9: Number of tourist arrivals and overnight stays (index 2020/2019)

\begin{tabular}{|l|l|l|l|l|l|l|l|l|l|l|l|l|}
\hline Month & I & II & III & IV & V & VI & VII & VIII & IX & X & XI & XII \\
\hline Arrivals & & & & & & & & & & & & \\
\hline Total & 124,2 & 118,9 & 44,0 & 2,1 & 12,4 & 47,5 & 49,5 & 65,7 & 56,9 & 50,7 & 38,7 & 32,9 \\
\hline Domestic & 120,2 & 122,7 & 53,0 & 3,1 & 20,0 & 83,7 & 96,6 & $\mathbf{1 2 5 , 3}$ & $\mathbf{1 0 8 , 9}$ & 79,3 & 57,5 & 51,7 \\
\hline Foreign & 128,7 & 113,5 & 34,2 & 0,8 & 2,2 & 13,3 & 11,3 & 12,9 & 17,1 & 25,0 & 20,7 & 15,3 \\
\hline $\begin{array}{l}\text { Overnigh } \\
\text { t stays }\end{array}$ & & & & & & & & & & & & \\
\hline Total & 125,1 & 120,1 & 54,3 & 5,4 & 17,4 & 56,7 & 64,1 & 82,9 & 77,1 & 62,5 & 53,6 & 40,1 \\
\hline Domestic & 122,5 & 120,8 & 62,8 & 6,0 & 23,6 & 82,8 & 96,8 & $\mathbf{1 2 3 , 1}$ & $\mathbf{1 1 8 , 8}$ & 85,1 & 71,1 & 53,3 \\
\hline Foreign & 128,7 & 118,6 & 41,7 & 4,2 & 5,6 & 15,2 & 14,7 & 16,3 & 23,7 & 33,8 & 32,0 & 24,4 \\
\hline
\end{tabular}

Source: Authors, according to Monthly Statistical Bulletin for 2020 (Statistical Office of the Republic of Serbia, 2020a)

The number of domestic tourists and overnight stays began to grow with the relaxation of measures, the arrival of summer and vacations and in August and September there was not only a return to the level of 2019 but even an increase compared to 2019 (arrivals - in August 125.5\%, September 108.9\%; Overnight stays - August 123.1\%, September 118.8\%). At the same time, the number of foreign tourists and their overnight stays also increased but slightly, i.e. the decrease compared to 2019 was still huge. 
Figure 10: Tourist overnight stays Nov. 2019 - Nov. 2020

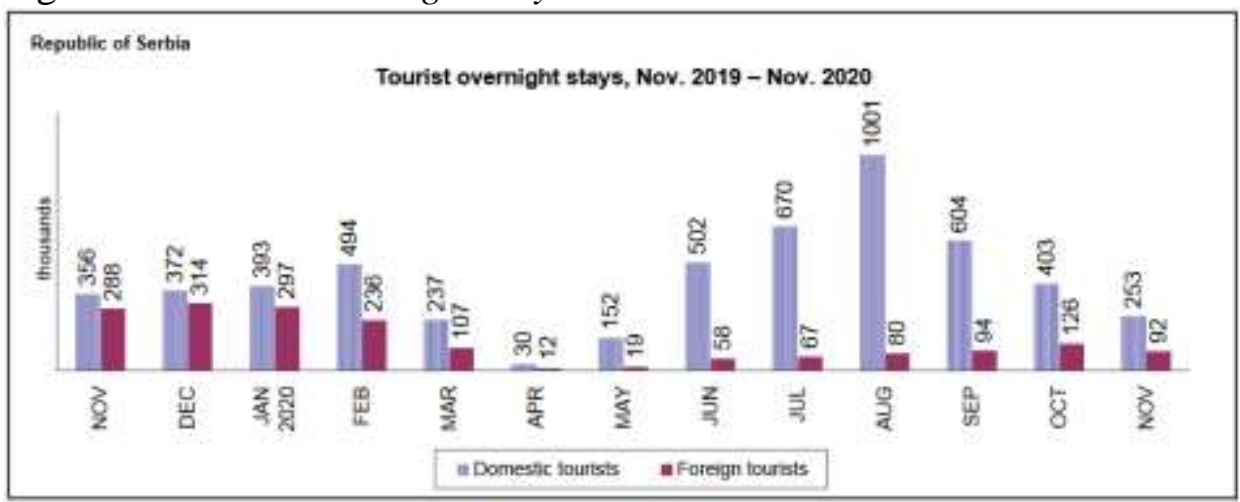

Source: Statistical Office of the Republic of Serbia, $2020 \mathrm{~b}$

Quarter trends of Statistical Office of the Republic of Serbia, more clearly represent this decline.

Figure 11: Tourist overnight stay, quarterly indices (\%) (Comparison with the same period of the previous year)

\begin{tabular}{|c|c|c|c|c|c|c|c|c|c|c|c|}
\hline & \multicolumn{4}{|c|}{2018} & \multicolumn{4}{|c|}{2019} & \multicolumn{3}{|c|}{2020} \\
\hline & 01 & Q2 & as & Q4 & at & $Q_{2}$ & 03 & Q4 & a1 & $\infty 2$ & 0.3 \\
\hline Total & 110.7 & 113,9 & 113.4 & $109: 1$ & 103,9 & 1072 & 105.6 & 116,6 & 98.3 & 28,1 & 749 \\
\hline Domestic tourists & 109.2 & 113.6 & 110.2 & 105.7 & 101.3 & 107.5 & 105.4 & 173.6 & 101.5 & 39.3 & 113.0 \\
\hline Foreign tourists & 113.5 & 114.5 & 118.6 & 112,3 & 106.3 & 106.4 & 105.8 & 120.6 & 93.2 & 89 & 179 \\
\hline
\end{tabular}

Source: Statistical Office of the Republic of Serbia (2020a)

An important question for tourism workers, due to further analysis and potential tourist offers, may be: Which places did tourists visit the most? Answers are given by the Statistical Yearbook of the Republic of Serbia for 2020. It shows: "Out of the total number of tourists' nights (10073 thousand), 27.6\% (2782 thousand) were recorded in spas and 22.9\% (2302 thousand) in mountain resorts" (Statistical Yearbook of the Republic of Serbia for 2020):

- The structure of domestic tourists' nights shows that $40.0 \%$ was spent in spas (2427 thousand) and 31.7\% (1919 thousand) in mountain resorts, out of the total number of domestic tourists' nights (6063 thousand).

- The structure of foreign tourists' nights shows that there were $54.2 \%$ (2172 thousand) of tourists in Grad Beograd, 7.0\% (279 thousand) in Grad Novi Sad, 8.8\% (354 thousand) in spas and 9.6\% (383 thousand) in mountain resorts, out of the total number of foreign tourists' nights (4010)". 
The Tourist Organization in Sokobanja told news agency Tanjug that the visit during the summer months of this year (2020) is $20 \%$ better than in the same period last year. The tourist organization of Vrnjačka Banja reported that July is a record month and that they noticed an increase in the number of guests by 16 percent. 150,000 overnight stays, i.e. 40,000 visits, were realized. They had primarily guests from Belgrade and places from Vojvodina (Mondo.rs, 2021).

Domestic tourists, in the absence of the possibility to travel abroad, looked for opportunities inside the country and places that would be interesting to visit. They visited traditionally known tourist places, but lesser-known tourist places in Serbia as well, who with a good offer and promotion (primarily via the Internet), found their position on the tourist market.

In the next period probably the largest portion of tourist activities will be connected with domestic tourists, due to difficult international transport, border closure and other measures that are still present. This should be the reason touristic sector need to more closely communicate with domestic tourists and adjust supply and products to their needs and demands.

\section{Communication with domestic tourists as important aspect in strategies for dealing with the effects of the pandemic in tourism}

"Today's organizations operate in a global environment, regardless of whether they are from production or service industry. Although the term globalization is used to describe the process of integration of markets and production globally, globalization is a process that can be viewed from multiple angles, as economic globalization, political globalization, cultural globalization, etc. Each of these aspects of globalization affect tourism, the providers and users of tourist services" (Cvetkovska Ocokoljić \& Babić, 2016, p. 485). With COVID-19, the interrelationships between pandemics and tourism became fully clear. Globalization means that urban and tourist centers are now more connected by plane, train, shipping and road. "A passenger, and therefore a disease, can now travel from one urban center to another the other side of the world in a day" (Hall et al., 2020, p. 579).

The tourism sector, at the beginning of COVID-19 pandemic, started with "the modification of cancellation policies, there was present increase in new partnerships, and an emphasis on increasing quality and marketing activity in the search for new customers" (Richards \& Morrill, 2021, p. 5). From one side they need to reduce their capacity to adjust to falling 
demand, but from another they need to increase marketing budgets in order to find new customers for their products, mainly to domestic markets.

Figure 12: Actions taken in response to the COVID-19 crisis

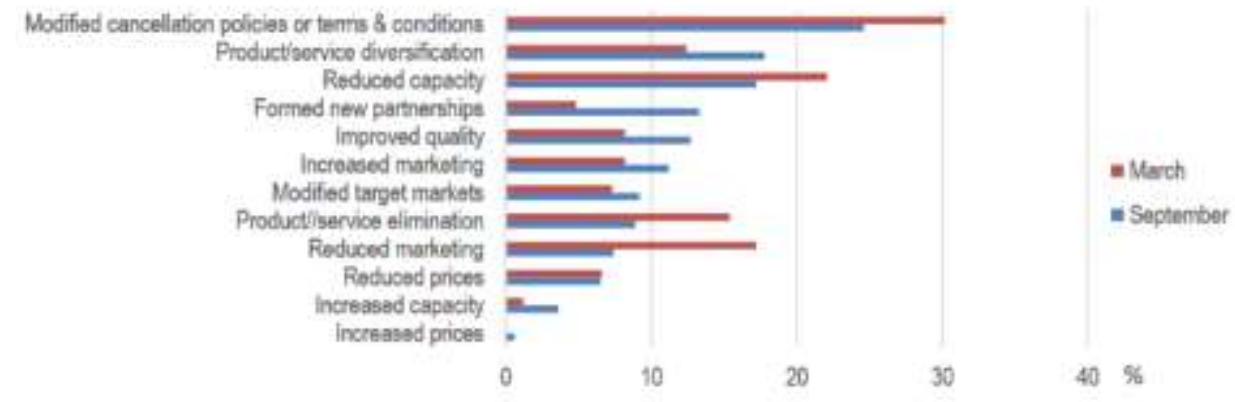

Source: Richards \& Morrill, 2021

Restrictions on travel and border closure were the first measures during COVID-19. Removal of those measures will be important step of tourism recovery. But while we wait for the borders to be opened and for possibility to travel abroad, we must rely on domestic tourists and domestic destinations, products and services. In order to encourage people to travel, countries will have to start with domestic tourism promotion campaigns. Demand for travel within the country decreased less than demand as a whole (for the whole market). We saw the same trend in Serbia, in 2020. Over $45 \%$ of respondents in Richards \& Morrill survey (2021, p. 5) "indicated that they had developed new products for domestic customers during the pandemic".

"While efforts are being made to market domestic tourism aggressively, there is a need to develop packages that are tailor-made for the domestic market. Competitive prices must be deliberately pursued as a means of building financial inclusion, and government can play a crucial role in making subsidies available for the sector to charge less for domestic travellers" (Woyo, 2018, p. 485). Domestic tourism is perceived to recover quicker to pre-COVID-19 levels compared to international travel in other contexts. However, for this to happen, there is a need to increase accessibility to domestic attractions. This is the reason why communication with domestic tourists is so important. We can talk about importance in order to find what those tourists needs and appreciations are, what price they can pay but also to inform them about our products and services. In 
this communication, all available means (media) should be used, and in particular organizations should rely on the use of new ICT.

Communication is mentioned, directly or indirectly, by many authors as one of the strategies for dealing with effects of Covid-19 pandemic. Hao et al. (2020, p. 14) outline a number of strategies in China's hotel industry "including diversification, product design and investment preference, digital and intelligent transformation, and market reshuffling". They suggested that "hotel firms need to re-evaluate the current business model and set out a new agenda to enhance competitiveness" (Hao et al., 2020, p. 14). "New technologies make communication easier and faster. It is easier to perceive the future service, to offer a service or to estimate it. With the help of new technologies it is easier to monitor competitors but also to improve or develop new tourism products and services. Tourism benefits from the new IC technologies" (Cvetkovska Ocokoljić \& Babić, 2016, p. 487).

Richards \& Morrill (2021) found that "The development of domestic travel products had a positive impact on business, with those developing new products" (p. 6). "In general, mutual respect, and understanding will help enable the tourists to have good time, meet new people and meet all those goals that are motivation for travel" (Langović Milićević \& Cvetkovski, 2016, p. 475). Richards \& Morrill (2021) also argue that in sectors "there was clear evidence of a digital shift, with products and services being offered online as a result of the pandemic. "This was most notable in the educational travel and language learning sectors, with over $40 \%$ of language programmes being offered online in some form" (Richards, \& Morrill, 2021, p. 6). The core of communication is in mutual understanding. "Deeper instrumentalization of religion and culture can be observed in the language and speech. Thus, it can be determined what a viewpoint a speaker takes when he evaluates and perceives the world he describes" (Cvetkovska Ocokoljić \& Cvetkovski, 2010, p. 96). "The world of symbols, visual and mental images, as a sign, seal or deceptive reality is connected to the most receptive human sense - sight" (Cvetkovska Ocokoljić \& Cvetkovski, 2012, p.1903).

Obviously, in attracting domestic tourists as well as those from around the world "certain roles has the country, tourist organizations, travel agencies, hotel operators, restaurants, culture organizations, etc. because the tourist product is complex and the tourist experience is multi-layered. It is 
determined by many elements, as well as the expectations with which tourists come" (Cvetkovski \& Langović Milićević, 2018, p. 253).

But all the measures taken will not be enough if tourists do not know about them. Communication is a two-way process, which involves the reaction of the recipient of the message (Cvetkovski \& Cvetkovska Tomanović, 2017) and the reaction expected from tourists is measured by the number of tourists, the number of nights, and consumption during the stay. It is a process of social interaction and only mutual understanding can give the success.

\section{Conclusion}

It is likely that many trends such as sharing economy, mobile payment systems, virtual reality etc. will influence tourism products and services as well as business models in the future (OECD, 2020a). However, they are currently most affected by the COVID-19 pandemic, which appeared in the beginning of 2020 and still completely determines all spheres of our lives. The COVID-19 pandemic closed borders, restricted movement and social interaction, and hit the tourism sector the hardest. However, due to primarily restrictions on movement, international tourism has felt the consequences the most, and salvation is sought in domestic tourism. Until the pandemic, the race was mainly aimed at attracting foreign tourists, but now the tourist offer have to be specially adapted to domestic tourists, and good communication will generally play a key role in this process.

\section{References}

1. Cvetkovska Ocokoljić, V., Babić, S. (2016). The importance of culture and human resource management in tourism, The First International Scientific Conference, Tourism in Function of Development of The Republic of Serbia - Spa Tourism in Serbia and Experiences of Other Countries, Thematic Proceedings I, Vol. 1, No. 1, 485-501.

2. Cvetkovska Ocokoljić, V., Cvetkovski, T. (2010). The Influence of Religion on the Creation of National Identity in Serbia. JIMS - Journal of Identity and Migration Studies, Vol. 4, No. 2, 81-103.

3. Cvetkovska Ocokoljić, V., Cvetkovski, T. (2012). Mediji - alhemija društva prividnog preobražaja [Media - the alchemy of a society of apparent transformation]. Teme, Vol. 36, No. 4, 1901-1912. 
4. Cvetkovski, T., Cvetkovska Tomanović, V. (2017). Пословна комуникација - у савременим условима пословања, 2. допуњено издање, [Business communication - in modern business conditions, 2nd supplemented edition], John Nesbit University, Belgrade.

5. Cvetkovski, T., Langović Milićević, A. (2018). Intercultural communication and understanding - why and how to attract tourists from China?, The Third International Scientific Conference, Tourism in Function of Development of The Republic of Serbia - Tourism in the Era of Digital Transformation, Vol. 3, No. 2, 238-256.

6. Cvetkovski, T., Langović Milićević, A., Cvetkovska-Ocokoljić V. (2016). Culture, communications and tourism product (Kultura, komunikacia a produkt cestovneho ruchu), zbornik z medzinárodnej konferencie študentov, doktorandov a vedeckych pracovnikov, Príčiny a riešenia cestovného [ne]ruchu, Nitra, 27-40.

7. European Travel Commission (2020). European Tourism - Trends \& Prospects, Quarterly report 2/2020, Executive Summary, https://etccorporate.org/uploads/2020/07/ETC-Trends-Prospects-Q2-2020-ExecSummary-2.pdf (22 February 2021).

8. Eurostat, (2020). Domestic tourism recovers faster than foreign tourism, https://ec.europa.eu/eurostat/web/products-eurostat-news/-/DDN20201023-1 (21 February 2021).

9. Hall, C. M., Scott, D., Gössling, S. (2020). Pandemics, transformations and tourism: be careful what you wish for, Tourism Geographies - An International Journal of Tourism Space, Place and Environment, Vol. 22, No. 3, 577-598.

10. Hao, F., Xiao, Q., Chon, K. (2020). COVID-19 and China's hotel industry: Impacts, a disaster management framework, and post-pandemic agenda. International Journal of Hospitality Management, Vol. 90, Article 102636.

11. Langović Milićević, A., Cvetkovski, T. (2016). The Importance of Cultural Differences and Tourism Development, The First International Scientific Conference, Tourism in Function of Development of The Republic of Serbia - Spa Tourism in Serbia and Experiences of Other Countries, Thematic Proceedings I, Vol. 1, No. 1, 469-484. 
12. Ministry of Health of the Republic of Serbia (2021). https://covid19.rs, (22 February 2021).

13. Mondo.rs (2021). Domaći turisti spasli sezonu [Domestic tourists saved season] https://mondo.rs/Magazin/Stil/a1370859/Letovanje-Srbijaturisticka-sezona-domaci-turisti-Srbija.html, (22 February 2021).

14. OECD (2020a). OECD Tourism Trends and Policies 2020, https://doi.org/10.1787/6b47b985-en, (20 February 2021).

15. OECD (2020b). Tourism Policy Responses to the coronavirus (COVID-19), https://www.oecd.org/coronavirus/policy-responses/ tourism-policy-responses-to-the-coronavirus-covid-19-6466aa20/, $(20$ February 2021).

16. Richards, G., Morrill, W. (2021). The challenge of Covid-19 for youth travel. Revista anais brasileiros de estudos turísticos / abet, uiz de For a (Brasil), Vol. 11, 1-8. https://www.academia.edu/45026980/THE_ CHALLENGE_OF_COVID_19_FOR_YOUTH_TRAVEL, (21 February 2021).

17. Statistical Office of the Republic of Serbia (2020b). Statistical release, Vol. LXX, No. 348, Catering and tourism statistics, https://publikacije.stat.gov.rs/G2020/PdfE/G20201348.pdf, (21 February 2021).

18. Statistical Office of the Republic of Serbia (2020c). Statistical Yearbook of the Republic of Serbia 2020, https://publikacije.stat.gov.rs/G2020/PdfE/G20202053.pdf, (21 February 2021).

19. Statistical Office of the Republic of Serbia, (2020a). Trends, III Quarter 2020, https://publikacije.stat.gov.rs/G2020/PdfE/G20208005.pdf, February 2021).

20. UNWTO (2021a). Barometer 2020: Worst Year in Tourism History with 1 Billion Fewer International Arrivals, https://www.unwto.org/ taxonomy/term/347, (12 February 2021).

21. UNWTO (2021b). Tourism Recovery Tracker, https://www.unwto.org/ unwto-tourism-recovery-tracker (20 February 2021). 
22. UNWTO (2020a). Tourism and Covid-19, https://webunwto.s3.euwest-1.amazonaws.com/s3fs-public/2020-04/COVID19_NewDS_.pdf, (15 February 2021).

23. UNWTO (2020b). Report: Travel Restrictions $8^{\text {th }}$, December 2020, https://www.unwto.org/covid-19-travel-restrictions, (15 February 2021).

24. UNWTO (2020c). Covid-19: Putting people first, https://www.unwto.org/ tourism-covid-19-2020 (12 February 2021).

25. UNWTO (2020d). World Tourism Barometer, Vol. 18, No. 5, https://www.e-unwto.org/doi/pdf/10.18111/wtobarometereng.2020.18.1.5, (12 February 2021).

26. Woyo E. (2021). The Sustainability of Using Domestic Tourism as a Post-COVID-19 Recovery Strategy in a Distressed Destination. In: Wörndl W., Koo C., Stienmetz J.L. (eds.) Information and Communication Technologies in Tourism 2021., Springer, 476-489. 